URSZULA ANNA PAWLUCZUK ${ }^{1}$

Uniwersytet w Białymstoku

ORCID 0000-0002-1419-4788

\title{
ZAKONNICY MONASTERU W ŻYROWICACH W ŚWIETLE WIZYTACJI SPORZĄDZONEJ W 1823 ROKU
}

\section{Monks of the monastery at Żyrowice in the light of a visitation made in 1823}

Abstract

The article presents short biographies of the Basilians of the monastery in Zhyrovitse in the Lithuanian province, who were recorded in the last visitation carried out in 1823 . The Basilian monastery in Zhyrovitse was closed in 1828, and after the dissolution of the union in 1839, the monastic life associated with the Church returned to the monastery Orthodox.

Keywords: Basilians, Lithuanian Province, Zhyrovitse, monastery, Uniate Church

\begin{abstract}
Abstrakt
Artykuł przedstawia krótkie biografie bazylianów klasztoru w Żyrowicach w prowincji litewskiej, którzy zostali odnotowani w ostatniej wizytacji przeprowadzonej w 1823 r. Klasztor bazyliański w Żyrowicach został zamknięty w 1828 r., a po likwidacji unii w 1839 r. do monasteru powróciło życie monastyczne związane z Kościołem prawosławnym.
\end{abstract}

Słowa kluczowe: bazylianie, prowincja litewska, Żyrowice, monaster, Kościół unicki

$\mathrm{W}$ wyniku rozbiorów Rzeczypospolitej oraz zmian granic po pokoju w Tylży (1807) i Kongresie Wiedeńskim (1815) na terenie Imperium Rosyjskiego znalazło się pięć diecezji unickich: metropolitalna, połocka, włodzimierska, łucka i chełmska. Rosyjski Kościół Prawosławny i panujący w Rosji niechętnie odnosili się do unitów. Powszechnie uważano, że unici powinni wrócić do prawosławia. Latynizacja i polonizacja unitów stanowiła dodatkowy powód do podjęcia działań w tym kierunku. Po raz pierwszy planową akcję „nawracania” unitów przeprowadzono na Wołyniu i Podolu w latach 1793-1794. Wyniku prowadzonej akcji misyjnej, kierowanej przez biskupa Wiktora Sadkowskiego, na prawosławie przeszło około 200 parafii unickich i około miliona wiernych ${ }^{2}$.

\footnotetext{
1 Urszula Anna Pawluczuk, dr hab., historyk, specjalistka z zakresu historii Kościoła. Badaczka dziejów Kościoła prawosławnego i monastycyzmu wschodniego oraz relacji religijnych, narodowych, kulturowych w Europie Środkowo-Wschodniej. Autorka książek i artykułów poświęconych tej tematyce. E-mail: upraw@uwb.edu.pl.

2 E. Likowski, Dzieje Kościoła Unickiego na Litwie i Rusi w XVIII i XIX wieku, cz. 1, Warszawa 1906, s. 256; H. Dylągowa, Kościół unicki na ziemiach Rzeczypospolitej 1596-1918, „Przegląd Wschodni”, 1992/1993, t. 2, z. $2(6)$, s. 277.
} 
Po śmierci Katarzyny II akcja misyjna ustała ${ }^{3}$. Car Piotr I, choć nie lubił unitów, to ich nie prześladował. Za jego rządów restytuowano, obok istniejącego arcybiskupstwa połockiego, biskupstwa łuckie i brzeskie. Kościół unicki liczył wówczas 1500 parafii, 80 klasztorów bazyliańskich i 1428000 wiernych ${ }^{4}$. Aleksander I również nie zwalczał unitów. Po przejściu części unitów na obrządek łaciński wydał dekret zabraniający ich nawracania. Ukazem z 1805 r. podzielił Kolegium Duchowne na dwa niezależne departamenty: łaciński i unicki. W każdym z nich zasiadali duchowni właściwego obrządku. Takie postanowienie miało zapobiec dominacji duchowieństwa rzymskokatolickiego nad unickim. Aleksander I zgodził się ponadto na ustanowienie unickiej diecezji litewskiej. W konsekwencji w granicach Cesarstwa Rosyjskiego znalazły się cztery diecezje unickie: litewska, połocka, łucka i brzeska. Piąta diecezja unicka - chełmska znalazła się w granicach Królestwa Polskiego.

Zasadnicza zmiana polityki wyznaniowej caratu wobec unitów nastąpiła za panowania Mikołaja I. Car uważał duchownych unickich narodowości białoruskiej lub ukraińskiej za osoby powiązane z kulturą wschodnią, które należy pozyskać do prawosławia. Za jego rządów władze państwowe i cerkiewne więcej uwagi zwracały na pomoc ludności prawosławnej zamieszkującej zachodnie obszary Imperium Rosyjskiego. Carat popierał ideologię państwa prawosławnego opartego na symbiozie ,prawosławia, samowładztwa i narodowości rosyjskiej”. W odróżnieniu od poprzednika car Mikołaj I wspierał tendencje integrystyczne w Cerkwi prawosławnej ${ }^{5}$. W przypadku Kościoła unickiego dążono do oczyszczenia obrządku wschodniego z naleciałości łacińskich. Przywrócenie w cerkwiach unickich pełnej obrzędowości wschodniej miało być wstępem do bezkonfliktowego zjednoczenia z prawosławiem. „Nawracanie” unitów na prawosławie nie miało mieć charakteru jednorazowej akcji, lecz było zaplanowane na kilka lat. Główną rolę w tym procesie miał odegrać Józef Siemaszko, od 1828 r. stojący w centrum spraw obrządku greckokatolickiego. W nurt przemian, likwidacji unickich monasterów czy też powrotu wielu ośrodków monastycznych do prawosławia wpisał się również monaster Zaśnięcia Matki Bożej (Uspienski) w Żyrowicach, największy ośrodek kultowy na ziemiach białoruskich.

Zakonnicy uniccy, którzy zostali spisani w ostatniej wizytacji przeprowadzonej w $1823 \mathrm{r}$., byli ostatnimi odnotowanymi w źródłach jako bazylianie przed oficjalnym powrotem monasteru żyrowickiego do Kościoła prawosławnego. Likwidacja monasteru bazyliańskiego w Żyrowicach nastąpiła w 1828 r. Likwidacji dokonało Kolegium Greko-unickie wsparte przez rosyjskie władze państwowe, w celu przekazania majątku monasterskiego świeckiemu duchowieństwu unickiemu6 . Oficjalnym powodem była chęć odebrania funduszy

O polityce caratu wobec Kościoła unickiego por.: E. Likowski, Dzieje Kościoła Unickiego na Litwie i Rusi w XVIII i XIX wieku, cz. 1-2, Warszawa 1906; T. Śliwa, Kościót greckokatolicki na ,ziemiach zabranych” (1815-1839) i Kościól greckokatolicki w Królestwie Polskim (1815-1875), w: Historia Kościoła w Polsce, t. 2, cz. 1, red. B. Kumor, Z. Obertyński, Poznań 1979, s. 497-511; W. Kołbuk, Kościoły wschodnie na ziemiach dawnej Rzeczypospolitej 1772-1914, Lublin 1992; H. Dylągowa, Kościół unicki..., s. 276-287; taż, Dzieje unii brzeskiej, Warszawa 1996; A. Mironowicz, W związu z 150 rocznica synodu połockiego (1839-1989), w: Chrześcijaństwo w Związu Radzieckim w dobie pierestrojki i głasnosti, red. W. Grzeszczak, E. Śliwka, Pieniężno 1992, s. 138-146; M. Radwan, Carat wobec Kościoła greckokatolickiego w zaborze rosyjskim 1796-1839, Roma-Lublin 2001.

4 A. Mironowicz, Likwidacja unii kościelnej na soborze połockim (1839 r.), w: Bizancjum - Prawosławie - Romantyzm. Tradycja wschodnia w kulturze XIX wieku, red. J. Ławski, K. Korotki, Białystok 2004, s. 148.

5 S.W. Rimskij, Stosunki między Cerkwia prawosławna a państwem w Rosji w XIX wieku, w: Chrześcijaństwo $w$ dialogu kultur na ziemiach Rzeczypospolitej, red. S. Wilk, Lublin 2003, s. 402-411.

625 września 1819 r. księża uniccy katedralni na kapitularnym posiedzeniu w Żyrowicach skarżyli się na zabranie duchowieństwu świeckiemu przez bazylianów mnóstwa dóbr. E. Likowski, Dzieje Kościoła unickiego na Litwie 
pobazyliańskich z przeznaczeniem ich na utrzymanie wdów po zmarłych księżach unickich i wykształcenie ich dzieci ${ }^{7}$. Na zadania te odebrano majątek ruchomy i nieruchomy bazyliańskiemu monasterowi w Ławryszewie ${ }^{8}$. Bazylianów rozlokowano w innych klasztorach. W budynkach monasteru w Żyrowicach pozostawiono dwóch bazylianów (nauczycieli ze szkół żyrowickich) do prowadzenia nabożeństwa w cerkwiach żyrowickich oraz dwóch kolejnych do zarządzania majątkiem. Zlikwidowano szkołę powiatową i gimnazjum prowadzone przez bazylianów w monasterze w Żyrowicach ${ }^{9}$. Zamknięto bursę dla ubogiej młodzieży. W budynkach monasterskich ulokowano seminarium duchowne dla 150 uczniów dzieci z rodzin kapłanów i diaków ${ }^{10}$. Oficjalne otwarcie unickiego seminarium duchownego miało miejsce 7 października 1828 roku $^{11}$. Po likwidacji unii w 1839 r. monaster żyrowicki powrócił do tradycji wschodniego monastycyzmu ${ }^{12}$.

Wizytację ośrodka zakonnego przed jego likwidacją na 208 kartach sporządził i podpisał 25 września 1823 r. ówczesny protokonsultor prowincji litewskiej ks. Leinty (Leontius) Okołow $^{13}$. Ks. Okołow był bazylianinem, urodził się w 1764 r., a w 1784 r. wstąpił do bazy-

i Rusi w XVIII i XIX wieku, cz. 2, Warszawa 1906, s. 32-35. Por.: Rozporzadzenie Ministra spraw zagranicznych z 1822 roku, odnoszace się do zniesienia klasztorów bazyliańskich, w: tamże, s. 281-297; proces likwidacji unii w zachodnich guberniach por.: D. Lisiejczykaj, Swjatar u bielarsukim socyumie: prasapagrafija unijackaga duchowieństwa 1596-1839 gg., Minsk 2015, s. 60.

7 Bazylianie w Żyrowicach z własnych funduszy klasztornych utrzymywali od wielu lat 12 synów księży unickich, którzy szykowali się do stanu kapłańskiego. Opiekowali się młodzieżą, już kiedy uczęszczała do szkoły powiatowej, a następnie gimnazjalnej. Zarówno szkoła powiatowa jak i gimnazjum były prowadzone i utrzymywane przez bazylianów i mieściły się w budynkach monasterskich w Żyrowicach. Z notatek osiemdziesięcio-letniego starca Litwina Unity, „Przegląd Lwowski”, 1875, s. 100, 101; R. Dobrowolski, Szkoły bazyliańskie w Żyrowicach XVIII-XIX w., w: Małe miasta. Religie, red. M. Zemło, Lublin-Supraśl 2006, s. 411-467; Z. Niedziela, Szkoły bazyliańskie na Białorusi w świetle raportów Komisji Edukacji Narodowej, w: Unia brzeska. Geneza, dzieje i konsekwencje w kulturze narodów słowiańskich, red. R. Łużny, F. Ziejka, A. Kępiński, Kraków 1994, s. 363.

8 Jeden z najważniejszych prawosławnych ośrodków życia monastycznego na ziemi nowogródzkiej założony w I połowie XIII wieku. Z końca XIII lub początku XIV w. pochodzi wykonany w monasterze Ewangeliarz Ławryszewski. Por.: A. Mironowicz, Biskupstwo turowsko-pińskie w XI-XVI wieku, Białystok 2011, s. 176-178; T. Friedelówna, Ewangeliarz Lawryszewski. Monografia zabytku, Wrocław-Warszawa-Kraków 1974; N. Nikałajeū, Pałata Knihapisnaja, Minsk 1993, s. 54, 69, 134, 162, 199.

9 Bazylianie otworzyli szkołę w monasterze w Żyrowicach w 1631 roku. Otrzymała ona 11 maja 1710 r. przywilej od króla Augusta II. Rosyjskie Państwowe Archiwum Historyczne w Sankt Petersburgu [РДГА], Ф. 733, оп. 62, ед. хр. 389, л. 204. W 1804 r. szkołę przeorganizowano w gimnazjum, ale zachowano także szkołę powiatową. Oficjalny status gimnazjum szkoła żyrowicka otrzymała w 1826 r. I. Sorkina, Mjasteczki Bielarusi u kancy XVIIIpierwszaj pałowie XIX st., Wilnja 2010, s. 263.

10 Z notatek osiemdziesięcio-letniego starca Litwina Unity, s. 107.

11 Pjatidesjatiletie perenesenija Litowskoj duchownoj seminarii iz miesteczka Żirowice w gorod Wilnu 1845-1895, „Litowskija Jeparchialnyja Wiedomosti”, 1895, nr 40, s. 374; I. Sorkina, Mjasteczki Bielarusi u kancy XVIIIpierwszaj pałowie XIX st., s. 263.

12 W 1939 r. w prawosławnym litewskim diecezjalnym seminarium w Żyrowicach pracowało 8 wykładowców, uczyło się 141 seminarzystów na koszt seminarium, a także 65 seminarzystów na koszt własny. Ponadto w szkole powiatowej i szkole dla diaków było 6 nauczycieli, 58 uczniów utrzymywanych przez szkołę i 103 uczniów utrzymywanych z własnych pieniędzy. W 1945 r. seminarium duchowne przeniesiono do Wilna do budynków monasteru Św. Trójcy, a w monasterze w Żyrowicach utworzono niższe seminarium duchowne (w 1958 r. wykładało w nim 16 nauczycieli, a uczyło się130 seminarzystów). Seminarzyści mieszkali w budynkach seminaryjnych i na kwaterach prywatnych w miasteczku. Narodowe Historyczne Archiwum Białorusi w Grodnie [НГАБ], Ф. 1, оп. 28, ед. хр. 708, л. 15.

13 Sankt Petersburski Instytut Historii Rosyjskiej Akademii Nauk, Sankt Petersburg, Zespół nr 52 - kolekcja Pawła Dobrochotowa [dalej: Архив СПб ИИ РАН], ф. 52, оп. 1, ед. хр. 374 - opis: Wizytacja monasteru żyrowickiego z 1823 r., „Wiadomość o stanie klasztoru bazyliańskiego żyrowieckiego w gubernii grodzieńskiej, powiecie [...] diecezji brzeskiej położonego". Wcześniejszy opis klasztoru sporządził superior żyrowicki ks. Ignacy Baranowski 
liańskiego monasteru w Byteniu. Następnie uczył się w szkołach zakonnych w Antopolu, w Wilnie, Berezweczu i w Żyrowicach. Po ich ukończeniu duchowny uczył teologii moralnej i matematyki zakonników m.in. w Wilnie, Żyrowicach, w Ławryszewie, Antopolu ${ }^{14}$.

W świetle wizytacji z 1823 roku wśród zakonników bazyliańskich przełożonym - superiorem żyrowickim - był Jozafat Słobodzki ${ }^{15}$. Pełnił on też funkcję kasjera przysięgłego. Protokół powizytacyjny podaje, że bazylianin miał wówczas 58 lat (ur. w 1765). Wstąpił do zakonu, mając 15 lat. Nauki początkowe wymowy i filozofii pobierał zakonie, a w wieku 28 lat otrzymał święcenia kapłańskie. Teologii uczył się w Rzymie w Kolegium Propagandy Wiary (Sacra Congregatione de Propaganda Fidae), gdzie otrzymał stopień doktora teologii i filozofii 12 kwietnia 1794 roku. Stanowisko przełożonego klasztoru w Żyrowicach pełnił od 1814 roku.

Skromna nota o przełożonym żyrowickim Jozafacie Słobodzkim vel Słobódzkim, przedstawiona w protokole wizytacji z 1823 roku wymaga uzupełnienia. Wśród unitów był on postrzegany jako zamęczony za wierność Kościołowi unickiemu. Jak podaje spis duchowieństwa unickiego z końca XVIII wieku, Jozafat Słobodzki urodził się w 1766 roku $^{16}$. Pochodził ze szlachty litewskiej ${ }^{17}$. Nowicjat odbył w Torokaniach w 1781 r., gdzie przebywał rok i uczył się wymowy i gramatyki. Kolejno przebywał w monasterze w Antopolu w latach 1782-83, gdzie uczył się retoryki, a w Szkole Głównej Litewskiej w Wilnie w latach 1784-86 logiki, fizyki i matematyki (Uniwersytet Wileński, a w latach 1781-1797 Szkoła Główna Litewska). Po skończeniu tych nauk posłano go do monasteru bazyliańskiego we Włodzimierzu, gdzie podjął się nauczania zakonników i duchowieństwa w I klasie w 1787 r. We Włodzimierzu w latach 1788-1790 wykładał matematykę. Następnie wyjechał do Rzymu na 3 lata, gdzie uzyskał doktorat z teologii. Po powrocie do kraju w 1794 r. rok uczył fizyki w szkole klasztornej we Włodzimierzu. Kolejny rok poświęcił na wykłady retoryki i poetyki w szkole w Żyrowicach. Następnie cztery lata wykładał filozofię i matematykę w szkole bazylianów w Wilnie. W latach 1800-1809 uczył tych przedmiotów w Żyrowicach, piastując równocześnie wikariat w Żyrowicach. O. Jozafat Słobodzki jako nauczyciel oceniał obyczaje, pilność, zdolność do nauki i postępy uczniów ${ }^{18}$. Od 1803 r. był superiorem monasteru ${ }^{19}$. W latach

w 1797 roku, Архив СПб ИИ РАН, ф. 52, оп. 1, ед. хр. 202 - opis: „Klasztor Żyrowicki, Parafię i Szkoły Publiczne narodowe utrzymujący”. W powyższym archiwum zachowała się także wizytacja z 1720 r., a mianowicie „Visitatio monasterii Zyrovicensis a die 21 Aprilis 1720". Sporządzone w związku z wizytacją zestawienie, podające następujące informacje o 26 zakonnikach przebywających w unickim klasztorze bazylianów w Żyrowicach: imię i nazwisko, miejsce pochodzenia, wiek (zapewne w momencie sporządzenia zestawienia), data i miejsce złożenia ślubów zakonnych, wykształcenie, pełnione w klasztorze funkcje (kaznodzieja, spowiednik itp.), 1720.04.21. Język: łaciński. Архив СПб ИИ РАН, ф. 52, оп. 1, ед. хр. 153.

14 Архив СПб ИИ РАН, ф. 52, оп. 1, ед. хр. 305, л. 191v. - opis: „Alfabetyczny spis duchownych Kościoła unickiego: odnotowano nazwisko, imię, data urodzin, pełnione funkcje i urzędy oraz ewentualnie data zgonu. Cz. 4. Data wydania/powstania: [koniec XVIII w.]". W tym spisie bazylianin jest odnotowany jako Leontius Okołow.

15 Архив СПб ИИ РАН, ф. 52, оп. 1, ед. хр. 374, л. 152.

16 Архив СПб ИИ РАН, ф. 52, оп. 1, ед. хр. 305, л. 251.

17 J.M. Giżycki (Wołyniak), Bazylianie we Włodzimierzu i Tryhórach, Kraków 1912, s. 72-74.

18 W 1799 r. o. Słobodzki tak oceniał swoich uczniów: Wiktora Buczyńskiego, Klemensa Bielskiego, Stefana Janiszewskiego, Herakliusza Bema, Feliksa Chreptowicza, Władysława Połkotyckiego i Dawida Andrzejewskiego, Архив СПб ИИ РАН, ф. 52, оп. 1, ед. хр. 245 - opis: „Zdanie o braciach kończących filozofię w roku 1799 przez własnego ich profesora podane".

19 Lietuvos Mokslu Akademijos Biblioteka,Vilnius [LMAB], f. 3-892 - opis: „Jozafat Słobodzki O.S.B.M. post installationem in Superioram Monasterii Żyroviecenzis, Anno 1803". 
1810-1814 piastował urząd sekretarza prowincji litewskiej zakonu w Torokaniach ${ }^{20} \mathrm{i}$ w $1814 \mathrm{r}$. został obrany konsultorem i superiorem żyrowickim. We wrześniu 1814 r. Uniwersytet Wileński uznał dyplom doktora teologii przyznany mu w Rzymie. W 1818 r. zakon polecił mu wizytowanie klasztoru w Leszczu, a także zakonu tumińskiego i różańskiego. W 1825 roku z Żyrowic o. Słobodzkiego powołano do wyższej godności opata kobryńskiego. Z uwagi na niechęć o. Słobodzkiego do konwersji na prawosławie w okresie likwidacji unii stał się osobą usuwaną ze stanowisk i przenoszoną z klasztoru do klasztoru. Przebywał m.in. w monasterze torokańskim, skąd przeniesiono go do monasteru w Zahorowie, jak podaje Giżycki: „najsroższego więzienia dla niechcących się nawrócić Unitów nad którymi się tam znęcał okrutnie Dziubiński... kat byłych swych braci, Bazylianów, zamęczanych strasznie w tym monasterze"21. O. Słobodzki został przywieziony do monasteru w Zahorowie w styczniu 1841 r. i ,na samym początku obrabował go Dziubiński, zabierając pieniądze, jakie miał przy sobie, ubranie, sprzęty, które ze sobą przywiózł (imbryczek, filiżanki, łyżeczki), destynatora opackie zerwał z niego, przeznaczając na zamieszkanie izdebkę najgorszą w całym monasterze, nieopalaną, najmniejszą, z najwstrętniejszym powietrzem, przeznaczył go do najniższych posług, a potem przeniósł do jeszcze gorszej ubikacji połączonej z kloakami. Gdy zaś to wszystko nic nie pomogło i opat nie chciał cyrografu wydać, to go jeszcze okrutniej prześladował i nękał, aż bogobojny starzec Bogu ducha oddał dnia 4 marca 1841 r. (niekiedy podają datę śmierci kilka dni wcześniej), idąc po nagrodę za swoją stałość"22.

Przywiązanie o. Jozafata Słobodzkiego do Kościoła unickiego, a szczególnie do zakonu bazyliańskiego wynikało z jego formacji intelektualnej, duchowej, teologicznej i kanonicznej, a także wzorów do naśladowania, które miał w nowicjacie i szkołach bazyliańskich. Owa formacja była w duchu łacińskim i polskim, różna od tradycji bizantyjsko-słowiańskiej, w której ukształtował się Kościół prawosławny ze swym odrębnym od rzymskiego obrządkiem, duchowością, teologią i strukturą organizacyjną.

Zakon bazyliański zapewniał wykształcenie ogólne i teologiczne. W 1828 r. na 37 monasterów bazyliańskich prowincji litewskiej było dwóch superiorów urodzonych w obrządku unickim, pozostali przełożeni przeszli z obrządku łacińskiego ${ }^{23}$. W XVIII w. zakon bazylianów kontrolował całe wewnętrzne życie cerkiewne obrządku unickiego, jak również kształtował oblicze kulturalne społeczności ruskiej zachowującej obrządek unicki, który był wówczas mocno zakorzeniony na ziemiach litewskich, białoruskich i Podlasiu. Na tych terenach jednakże było kilka elementów, które spajały oba Kościoły wschodnie i ich wiernych,

\footnotetext{
20 Od 1743 roku bazyliański monaster w Torokaniach był jedną z dwóch siedzib protoarchimandryty (generała) zakonu bazyliańskiego litewskiej prowincji Świętej Trójcy, obok klasztoru w Poczajowie (prowincja koronna). W 1739 r. stworzono drugą Kongregację skupiającą klasztory z południowo-wschodniej Rzeczypospolitej, a w 1743 r. obie Kongregacje połączyły się w jeden Zakon Ruski św. Bazylego Wielkiego podzielony na dwie prowincje. W 1780 r. dokonano podziału zakonu na cztery prowincje: litewską, koronną (ruską), białoruską, galicyjską. J.M. Giżycki (Wołyniak), Siedziba bazylianów w Torokaniach, Kraków 1906, s. 30.

21 J.M. Giżycki (Wołyniak), Bazylianie we Włodzimierzu i Tryhórach, s. 73-74. Superiorem monasteru w Zahorowie był bazylianin ks. Seweryn Dziubiński, który przyjął prawosławie w 1840 r. Pochodził z Galicji. Dla zachowania wyższych urzędów, otrzymania honorów, wraz z nim prawosławie przyjęli także bazylianie: Hipacy Starodubowski, Jan Misiewicz, Ignacy Ihnatowicz. Z notatek osiemdziesięcio-letniego starca Litwina Unity, s. 693.

22 Po śmierci O. Słobodzkiego, ks. Dziubiński znaleziony został martwy w stawie w pobliskiej wsi Chorowa, koło Zahorowa, jak podaje Giżycki, że może poprzez wyrzuty sumienia odebrał sobie życie. J.M. Giżycki (Wołyniak), Bazylianie we Włodzimierzu i Tryhórach, s. 74.

23 Zapiski Iosifa, Mitropolita Litowskogo, izdannyje Imperatorskoju Akademieju Nauk, po zawieszczaniu awtora, t. 1, Sankt-Peterburg 1883, s. 598.
} 
a mianowicie niezwykle rozwinięty kult maryjny. Na początku XIX w. kilka klasztorów bazyliańskich posiadało słynące z cudów obrazy-ikony Bogarodzicy, znane społeczności prawosławnej od XV-XVI wieku, tj. obraz Najświętszej Marii Panny Hodigitrii znajdujący się w monasterze bazyliańskim w Wilnie (XV w.), obraz NMP - kopię ikony Hodigitrii smoleńskiej z monasteru supraskiego (pocz. XVI w.) czy też obraz NMP znajdujący się w monasterze żyrowickim. Żyrowice były niezwykle ważne dla bazylianów na pocz. XIX w., tak jak dla prawosławnych od wieków na ziemiach białoruskich. Interesujący jest także obraz Najświętszej Marii Panny, który nie powstał w środowisku prawosławnym, a w środowisku bazyliańskim w Borunach. Chrześcijanie różnych wyznań przybywali od końca XVII w., by prosić o łaski przed obliczem ikony NMP ${ }^{24}$. Obraz był ozdobiony srebrną pozłacaną szatą w „dętych srebrnych wyzłacanych ramach. Korony na głowach Jezusa i Matki Jego, obie złote. W koronie NMP dwa aniołki srebrne pozłacane"25.

Do grona zakonników żyrowickich w świetle wizytacji z 1823 r. należał ks. Jan Chryzostom Ławrynowicz, który był emerytem prowincji litewskiej i od $1819 \mathrm{r}$. sprawował funkcję archiwisty w monasterze w Żyrowicach ${ }^{26}$. Urodził się w 1749 r., a wstąpił do nowicjatu 13 lutego 1770 r. w monasterze byteńskim ${ }^{27}$. Święcenia kapłańskie otrzymał, mając 28 lat. Naukę podstawową, wymowę, filozofię i teologię pobierał w zakonie - w Torokaniach i Antopolu. W Wilnie 4 lata studiował teologię. Następnie podjął się nauczania przez dwa lata teologii moralnej w seminarium w Chełmie. Później nauczał w seminarium w Wilnie, kolejno także w Berezweczu i w Borunach ${ }^{28}$. Stosownie do swojej wiedzy otrzymywał zadania, funkcje czy urzędy w zakonie.

Pierwszym spowiednikiem w klasztorze był Olimpi Korewicki, w spisie z końca XVIII w. występuje jako Alimpius Korowicki ${ }^{29}$. Urodził się w 1754 r., a mając 16 lat wstąpił do zakonu w Żyrowicach, gdzie przebywał dwa lata. Uczył się przez rok retoryki w klasztorze w Antopolu i rok w Byteniu. W klasztorze w Witebsku uczył się przez rok filozofii. Teologię dogmatyczną studiował 3 lata w klasztorze w Borunach, a teologię dwa lata w klasztorze w Dubnie i rok w klasztorze w Dermaniu. W wieku 27 lat otrzymał święcenia kapłańskie. Na przełomie XVIII/XIX w. zajmował się działalnością misyjną bazylianów, przebywając w klasztorze w Sielcu i na parafii w Brahniu ${ }^{30}$. W Sielcu był także przez 5 lat wikarnym, a przez kolejne 3 lata superiorem. Od 1817 r. był spowiednikiem w Żyrowicach.

W świetle tej samej wizytacji drugim spowiednikiem w Żyrowicach był ks. Filip Oszurko mający 59 lat (ur. w 1764 r.) ${ }^{31}$. W spisie bazylianów z końca XVIII wieku występuje jako Filip Oskierko $^{32}$. Wstąpił do zakonu w Byteniu w wieku 18 lat, gdzie odbył nowicjat i przebywał

\footnotetext{
24 J.M. Giżycki, Bazyliańskie klasztory unickie w obrębie prowincji białoruskiej, „Przewodnik Naukowy i Literacki", 1907, t. 3, s. 186-187.

25 Lietuvos Valstybes Istorijos Archyvas [dalej: LVIA], f. 634, op. 1, t. 58, k. 59-74.

26 Архив СПб ИИ РАН, ф. 52, оп. 1, ед. хр. 374, л. 152.

27 Архив СПб ИИ РАН, ф. 52, оп. 1, ед. хр. 305, л. 150.

28 Por.: D. Wereda, Z dziejów sanktuarium i placówki oświatowej w Boruniach, „Nasza Przeszłość”, 2006, t. 105, s. 189-206; J.M. Giżycki, Wspomnienie o Borunach i unitach w Oszmiańskiem, „Muzeum”, 1907, t. 13, s. 645-666.

29 Архив СПб ИИ РАН ф. 52, оп. 1, ед. хр. 305, л. 124; ibidem, ф. 52, оп. 1, ед. хр. 374, л. 152.

${ }^{30}$ Misje bazylianów szczególnie zwrócone były w kierunku pogłębienia życia religijnego wśród ich wiernych, ale także pozyskania wiernych prawosławnych do konwersji na unię.

31 Архив СПб ИИ РАН, ф. 52, оп. 1, ед. хр. 374, л. 152.

32 Архив СПб ИИ РАН, ф. 52, оп. 1, ед. хр. 305, л. 195.
} 
łącznie 5 lat. Następnie życie zakonne kontynuował w Torokaniach przez 3 lata, w klasztorze w Antopolu 3 lata, a w klasztorze w Wilnie uczył się przez 3 lata retoryki. W klasztorze w Borunach przez 3 lata i kolejne 2 lata w klasztorze w Żyrowicach uczył się teologii. Mając 24 lata, otrzymał świecenia kapłańskie. Od 1821 roku był spowiednikiem w Żyrowicach.

Kaznodzieją ordynaryjnym w klasztorze w Żyrowicach od 1819 r. był ks. Teodor Zwirydowski, mający w roku wizytacji 36 lat (ur. w 1787 r.) ${ }^{33}$. Do klasztoru wstąpił, mając 15 lat, a święcenia kapłańskie otrzymał w wieku 24 lat. Uczył się w szkołach świeckich, podstawy wymowy i teologii uzyskał w zakonie. Ponadto studiował filozofię na Uniwersytecie Cesarskim w Wilnie (Uniwersytet Wileński od 1803 r. jako Cesarski Uniwersytet Wileński, w randze kuratorium, organizował i nadzorował szkolnictwo Wileńskiego Okręgu Nauk), gdzie otrzymał stopień kandydata filozofii. Nie oznaczało to ukończenia studiów ze stopniem magistra, a najczęściej wysłuchanie i ukończenie na studiach cyklu wykładów ${ }^{34}$.

Dozorcą szkoły w Żyrowicach i nauczycielem matematyki był, od 26 lipca 1819 r. do 1823 r., ks. Numerian Hryniewicz, mający w roku wizytacji 43 lata (ur. w 1780 r.) ${ }^{35}$. W spisie bazylianów z końca XVIII w. występuje jako Numerianus Hryckiewicz ${ }^{36}$. Wstąpił do klasztoru, mając 23 lata. Święcenia kapłańskie otrzymał w wieku 26 lat. Uczył się w szkołach świeckich nauk początkowych i wymowy w Berezweczu i w Borunach, nauk filozoficznych i teologicznych w zakonie - przez rok uczył się w żyrowickim studium zakonnym. Ukończył studia na Uniwersytecie Cesarskim w Wilnie ze stopniem kandydata filozofii - 5 października 1807 r. i magistra teologii - 14 czerwca 1809 r. Po studiach ks. Hryniewicz (Hryckiewicz) był nauczycielem w szkole bazyliańskiej w miejscowości Lady. Do klasztoru w Żyrowicach przyjechał 13 października 1814 r. i przez dwa lata uczył filozofii. Od 19 sierpnia 1816 r. był nauczycielem teologii w klasztorze Św. Trójcy w Wilnie. Ponownie przybył do Żyrowic w 1819 r. Następnym dozorcą szkoły był ks. Józef Ordanowicz, który w Żyrowicach pełnił tę funkcję do 1826 roku.

Nauczycielem historii, geografii, nauk moralnych i religii w klasach wyższych był ks. Wincenty Lisowski, wówczas mający 43 lata (ur. w 1780 r.) ${ }^{37}$. Inne źródła podają że urodził się w 1778 r. ${ }^{38}$ Pochodził z rodziny szlacheckiej z powiatu dziśnieńskiego. Wstąpił do klasztoru, mając 13 lat. Święcenia kapłańskie otrzymał w wieku 23 lat. Swoje funkcje

\footnotetext{
33 Архив СПб ИИ РАН, ф. 52, оп. 1, ед. хр. 374, л. 152; tamże, ф. 52, оп. 1, ед. хр. 305, л. 331v - w tym spisie z końca XVIII w. jest podane jedynie imię i nazwisko bez opisu.

34 J. Wołczukowska, Zakonnicy jako nauczyciele języka rosyjskiego w szkołach Wileńskiego Okręgu Naukowego w latach 1787-1832, „Roczniki Humanistyczne”, 1988, t. 26, z. 7, s. 100; W 1828 r. sporządzono zestawienie unitów, którzy od 1808 r. studiowali na Uniwersytecie w Wilnie, a ściślej funkcjonującym przy uniwersytecie od 1803 r. Seminarium Głównym. Według tego zestawienia w tym okresie studiowało 64 unitów z 4 diecezji unickich (Połock, Brześć, Łuck, Wilno), a ukończyło studia 40. Warto dodać, że bazylianie studiowali również na kierunkach uniwersyteckich poza Seminarium Głównym i w świetle danych z 1822 r. bazylianów tak studiujących było 24. D. Beauvois, Wilno - polska stolica kulturalna zaboru rosyjskiego 1803-1832, Wrocław 2012, s. 292-293.

35 Архив СПб ИИ РАН, ф. 52, оп. 1, ед. хр. 374, л. 152; LVIA, f. 567, op. 2, t. 964, k. 145 v-146; LVIA, f. 567 , op. 2, t. 1275, k. 202. Przed ks. Hryniewiczem dozorcą szkoły był m.in. ks. Bazyli Dessarz (1801-1805), ks. Julian Fiedorowicz 1806[?]-1807, ks. Joachim Jastrzębowski 1807-1808, ks. Lucyd Ostaszewski 1808-1810, ks. Maksymilian Lebell [?]-1814[?], ks. Jozafat Żarski 1815-1817, ks. Szymon Kotowicz 1818-1819. R. Dobrowolski, Szkoły bazyliańskie w Żyrowicach XVIII-XIX w., s. 442.

36 Архив СПб ИИ РАН, ф. 52, оп. 1, ед. хр. 305, л. 331v - w tym spisie z końca XVIII w. jest podane jedynie imię i nazwisko bez opisu.

37 Архив СПб ИИ РАН, ф. 52, оп. 1, ед. хр. 374, л. 152-153.

38 LVIA, f. 567 , op. 2, t. 682 , k. $87-88$.
} 
w Żyrowicach wykonywał od 1814 roku. Uczył się nauk początkowych, wymowy, filozofii i teologii w zakonie. Wstąpił do zakonu najpierw w Berezweczach, potem był w monasterze w Byteniu od 1797 r., następnie w Antopolu ${ }^{39}$. Uczył się także w latach 1803-1804 w Torokaniach w studium zakonnym, przez następne dwa lata był słuchaczem teologii w Żyrowicach. W latach 1806-1807 nauczał teologii moralnej w bazyliańskim seminarium diecezjalnym w Świerżeniu. Kolejne dwa lata był prezesem konwiktu funduszowego w Wilnie. W latach 1809-1813 przebywał w Borunach, gdzie pełnił funkcję przełożonego szkoły publicznej (od 1811) i nauczał prawa, geografii i nauk moralnych. W kolejnych latach pełnił funkcję wikarego klasztorze w Helianowie ${ }^{40}$.

W okresie omawianej wizytacji nauczycielem wymowy, a także języka francuskiego i niemieckiego, już od 4 lat był ks. Bartłomiej Lewkowicz, wówczas mający 33 lata (ur. w 1790 r. ${ }^{41}$. Wstąpił do zakonu, mając 17 lat. Otrzymał święcenia kapłańskie w wieku 32 lat. Uczył się w szkołach świeckich nauk początkowych, wymowy i teologicznych w zakonie, studiował na Uniwersytecie Cesarskim w Wilnie, gdzie ukończył filozofię.

Nauczycielem fizyki i języka rosyjskiego od 1822 roku był diakon Andrzej Sawicz. W roku wizytacji miał 26 lat (ur. w 1797 r. $)^{42}$. Inne źródła podają, że urodził się w 1791 r. i pochodził z powiatu słonimskiego ${ }^{43}$. Wstąpił do zakonu, mając 14 lat. Święcenia diakońskie otrzymał w wieku 22 lat. Uczył się nauk początkowych i wymowy w zakonie, ukończył ze stopniem kandydata filozofii Uniwersytet Cesarski w Wilnie.

Nauczycielem gramatyki polskiej i łacińskiej był ks. Maurycy Zieliński, mający wówczas 29 lat (ur. w 1794 r. $)^{44}$. Wstąił do zakonu w wieku 16 lat. Święcenia kapłańskie otrzymał w wieku 25 lat. Uczył się nauk początkowych i wymowy w zakonie, ukończył filozofię na Uniwersytecie Cesarskim w Wilnie.

Nauczycielem arytmetyki, geografii, nauk moralnych i religii w dwóch pierwszych klasach był w czasie wizytacji ks. Sylwester Bielski, mający wówczas 28 lat (ur. w 1795 r.) (45 $^{45}$, który pełnił te funkcje już rok. Pochodził z powiatu mińskiego i był synem Jana Bielskiego. Wstąpił do zakonu, mając 18 lat. Otrzymał święcenia kapłańskie w wieku 24 lat. Uczył się nauk początkowych i wymowy w zakonie. Ks. Bielski, będąc nauczycielem w Żyrowicach, także się dokształcał, bowiem był studentem filozofii na Uniwersytecie Cesarskim w Wilnie. W źródłach z $1826 \mathrm{r}$. jest mowa, że nadal pełnił te funkcje ${ }^{46}$.

Posługę zakrystiana (nadzorował zakrystię i dbał o porządek w cerkwi, m.in. wyznaczał zakonników do odprawiania nabożeństw) w Żyrowicach pełnił ks. Taracjusz Teodorowicz ${ }^{47}$. Zakrystianem w świetle protokołu był od 17 lat. W roku wizytacji miał 57 lat (ur. w 1766 r.). Wstąpił do zakonu, mając 20 lat. Otrzymał święcenia kapłańskie w wieku 30 lat. Uczył się w zakonie teologii moralnej.

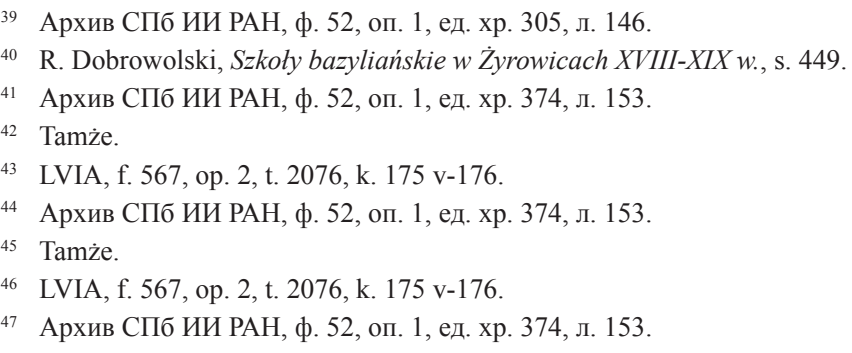


Funkcję prokuratora domowego - ekonoma w Żyrowicach od 1812 roku pełnił ks. Augustyn Dołubowski ${ }^{48}$. W roku wizytacji miał 39 lat (ur. w 1784 r.). Wstąpił do zakonu, mając 23 lata. Otrzymał święcenia kapłańskie w wieku 29 lat. Uczył się w zakonie teologii moralnej.

Od 1818 roku parochem (proboszczem, plebanem) w Żyrowicach był ks. Jozafat Monkiewicz $^{49}$. W roku wizytacji miał 32 lata (ur. w 1791 r. ). Wstąpił do zakonu, mając 22 lata. Otrzymał święcenia kapłańskie w wieku 25 lat. Uczył się w zakonie teologii moralnej.

Funkcję trapeznego sprawował od 1821 roku diakon Faustyn Czarniakiewicz. W roku wizytacji miał 24 lata ( ur. w 1799 r.) (5) $^{50}$ Wstąpił do zakonu, mając 17 lat. Otrzymał święcenia diakońskie w wieku 21 lat. Uczył się w zakonie nauk początkowych.

Od roku 1822 funkcję szafarza pełnił profes żyrowicki Izydor Puciłowski ${ }^{51}$. W roku wizytacji miał 26 lat (ur. w 1797 r.). Wstąpił do zakonu w wieku 22 lat. Miał znajomość nauk początkowych.

Nauczycielem wymowy i języka francuskiego w szkole zakonnej w Żyrowicach był ks. Jozafat Rzecki ${ }^{52}$. W roku wizytacji miał 30 lat (ur. w 1793 r.). Wstąpił do zakonu w wieku 14 lat. Otrzymał święcenia kapłańskie w wieku 24 lat. Uczył się nauk początkowych i filozofii w zakonie. Na Uniwersytecie Cesarskim w Wilnie ukończył ze stopniem kandydata filozofię i studiował teologię ${ }^{53}$. Ks. Rzecki zaliczał się do bazylianów, którzy w swoich szkołach nauczali języka rosyjskiego.

W sytuacji porozbiorowej w szkołach bazyliańskich język rosyjski pojawił się przed rokiem 1803. W guberniach litewskich i mińskiej języka rosyjskiego nauczali przede wszystkim zakonnicy bazylianie ${ }^{54}$. Ponadto większość nauczycieli bazylianów wykładało po kilka przedmiotów z uwagi na braki kadrowe. W świetle protokołu z wizytacji od 1822 r. języka rosyjskiego uczył wspomniany diakon Andrzej Sawicz. Uczył on także fizyki. Przed nim języka rosyjskiego uczyli w Żyrowicach m.in.: w latach 1803-1808 ks. Julian Spirydowicz, który uczył także fizyki, a nieco później ks. Faustyn Sobolewski ${ }^{55}$. Ks. Julian Spirydowicz (ur. w 1770 r.) pochodził z powiatu połockiego. Otrzymał nauki początkowe w klasztorze w Berezweczu, a edukację wyższą w studium zakonnym. Studiował także fizykę eksperymentalną na Uniwersytecie Cesarskim w Wilnie. Natomiast ks. Faustyn Sobolewski (ur. w 1783 lub 1784 r.) pochodził z rodziny szlacheckiej powiatu nowogródzkiego. Ukończył

\footnotetext{
48 Tamże.

49 Tamże.

50 Tamże.

51 Tamże, ф. 52, оп. 1, ед. хр. 374, л. 154.

52 Tamże.

53 Spośród 52 odnotowanych bazylianów, którzy uczyli języka rosyjskiego, przy 28 nazwiskach można znaleźć w ankietach personalnych uwagę: „uczył się w Wilnie”. Zazwyczaj nie oznaczało to ukończenia studiów, najczęściej jedynie uzyskanie tytułu ,kandydata” lub wysłuchanie cyklu wykładów (zazwyczaj z przedmiotów matematyczno-fizycznych i przyrodniczych, rzadziej humanistycznych). Tytuł „kandydata” mieli bazylianie: Faustyn Bełdowski, Wiktor Bosiacki, Bazyli Bryngk, Walerian Kuczyński, Ambroży Parmanowski, Jozafat Rzecki, Mikołaj Siatkowski, Porfiry Siatkowski; jako studiujący przedmioty przyrodnicze i matematyczno-fizyczne wykazani są: Marcin Butrymowicz, Stefan Janiszewski, Hieronim Judziewicz, Porfiry Lewski, Julian Spirydowicz; magistrem filozofii był Piotr Szpakowski, a teologię studiował Benedykt Homolicki; przy pozostałych nazwiskach brak informacji o kierunku studiów. Materye na publiczny popis uczniow szkoły Żyrowickiej [...] r. 1816, Wilno [b.r.] [bez paginacji]; J. Wołczukowa, Zakonnicy jako nauczyciele języka rosyjskiego, s. 100,101.

54 J. Wołczukowa, Język „,słowiański” (ruski) w szkołach polskich za czasów Komisji Edukacji Narodowej, „Przegląd Rusycystyczny", 1984, nr 4, s. 15-32.

55 Taż, Zakonnicy jako nauczyciele języka rosyjskiego, s. 100.
} 
studium zakonne i studiował fizykę, chemię, matematykę i astronomię na Uniwersytecie Cesarskim w Wilnie ${ }^{56}$.

Do braci zakonnej bazylianów w Żyrowicach należeli w świetle danych z wizytacji także ci, którzy uczęszczali do szkoły żyrowickiej ${ }^{57}$. Spośród nich większość stanowili bazylianie, którzy złożyli profesję w Żyrowicach. Uczniami wymowy i matematyki w 1823 r. byli: subdiakon Jan Owelt (26 lat, wstąpił do zakonu w wieku 19 lat), profes żyrowicki Jerzy Jaczynowski (23 lata, wstąpił do zakonu w wieku 15 lat), profes żyrowicki Sylwester Zadarnowski (21 lat, wstąpił do zakonu w wieku 14 lat), profes żyrowicki Chryzostom Swirkowicz (22 lata, wstąpił do zakonu w wieku 16 lat), profes żyrowicki Jakub Szachnowski (22 lata, wstąpił do zakonu w wieku 16 lat), profes żyrowicki Innocenty Ostrowski (24 lata, wstąpił do zakonu w wieku 20 lat), diakon Gerwazy Maszalski (26 lat, wstąpił do zakonu w wieku 20 lat, święcenia diakońskie otrzymał, mając 23 lata), profes żyrowicki Chryzostom Maszalski (21 lat, wstąpił do zakonu w wieku 17 lat), profes żyrowicki Antoni Wokulski (20 lat, wstąpił do zakonu w wieku 15 lat), profes żyrowicki Samuel Czarnorucki ${ }^{58}$ (25 lat, wstąpił do zakonu w wieku 19 lat), profes żyrowicki Tomasz Skibiski (20 lat, wstąpił do zakonu w wieku 14 lat), profes żyrowicki Sebastian Dobiszewski (20 lat, wstąpił do zakonu w wieku 15 lat), profes żyrowicki Jakub Sarnacki (22 lata, wstąpił do zakonu w wieku 17 lat), profes żyrowicki Joachim Bobrowicz (20 lat, wstąpił do zakonu w wieku 13 lat), profes żyrowicki Benedykt Filipowicz (21 lat, wstąpił do zakonu w wieku 16 lat), profes żyrowicki Jazon Łazowski (24 lata, wstąpił do zakonu w wieku 20 lat), profes żyrowicki Seweryn Chalimowicz $^{59}$ (22 lata, wstąpił do zakonu w wieku 18 lat), profes żyrowicki Eugeniusz Chrulkiewicz (20 lat, wstąpił do zakonu w wieku 15 lat), kandydat Onufry Sawoniewicz ${ }^{60}$ (21 lat, wstąpił do zakonu w wieku 16 lat), kandydat Korneli Błażewicz (18 lat, wstąpił do zakonu w wieku

\footnotetext{
56 R. Dobrowolski, Szkoly bazyliańskie w Żyrowicach XVIII-XIX w., s. 446.

57 Архив СПб ИИ РАН, ф. 52, оп. 1, ед. хр. 374, л. 154.

58 Występuje także jako Czarnorudzki, Czarnoruski. Bazylianina ks. Samuela Czanoruckiego z uwagi na niechęć do konwersji na prawosławie odizolowano w Torokaniach dwa razy: w roku 1836 i 1840. Opisał to w swoim pamiętniku opublikowanym: $Z$ notatek osiemdziesięcio-letniego starca Litwina Unity, s. 689- 694; J.M. Giżycki (Wołyniak), Siedziba bazylianów w Torokaniach, s. 43, 44.

59 Występuje jako administrator rzymskokatolickiej parafii Św. Judy Tadeusza w Łuczaju w latach 1859-1872. Parafia została utworzona w 1755 roku. Dzisiaj znajduje się na Białorusi (biał. Парафія Св. Юды Тадэвуша у Лучаi) i należy do dekanatu postawskiego diecezji witebskiej.

${ }_{60}$ Bazylianin w 1866 roku występuje jako archimandryta prawosławnego monasteru Uspieńskiego/Zaśnięcia NMP w Tadulinie. W tym czasie w monasterze mieszkało wraz z archimandrytą Onufrym Sawoniczem 10 zakonników: o. Antoni Toczicki (jeromonach), o. Benedykt Radzimiński, o. Piotr Lebiedziew, o. Fiodor Zabłocki, o. Gerazim Obrazski, o. Paweł Zabrzewicz (diakon) i 3 nowicjuszy. W Tadulino w 1773 r. istniał klasztor bazyliański i kościół pw. Narodzenia NMP, w którym mieszkało 5 duchownych. Klasztor bazyliański skasowano w 1836 r. i ulokowano monaster prawosławny męski. W 1909 r. monaster był przekształcony w żeński. W 1879 r. nastąpiła przebudowa nawy głównej i ustawienie na niej kopuły, tak by upodobnić wygląd świątyni do cerkwi. Zmieniono nazwę kompleksu klasztornego, bowiem w II połowie XIX w. występuje jako klasztor prawosławny pw. Świętej Trójcy. Bazylianin w 1866 roku występuje jako archimandryta prawosławnego monasteru Uspieńskiego/Zaśnięcia NMP w Tadulinie. W tym czasie w monasterze mieszkało wraz z archimandrytą Onufrym Sawoniczem 10 zakonników: o. Antoni Toczicki (jeromonach), o. Benedykt Radzimiński, o. Piotr Lebiedziew, o. Fiodor Zabłocki, o. Gerazim Obrazski, o. Paweł Zabrzewicz (diakon) i 3 nowicjuszy. W Tadulino w 1773 r. istniał klasztor bazyliański i kościół pw. Narodzenia NMP, w którym mieszkało 5 duchownych. Klasztor bazyliański skasowano w 1836 r. i ulokowano monaster prawosławny męski. W 1909 r. monaster był przekształcony w żeński. W 1879 r. nastąpiła przebudowa nawy głównej i ustawienie na niej kopuły, tak by upodobnić wygląd świątyni do cerkwi. Zmieniono nazwę kompleksu klasztornego, bowiem w II połowie XIX w. występuje jako klasztor prawosławny pw. Świętej Trójcy. J. Fibek, Tadulin - bazyliański klasztor p.w. Narodzenia NMP, http://www.radzima.org/be/ object_comm/7504.html (dostęp 23.04.2021).
} 
13 lat). Wymienieni uczniowie uczęszczali w zdecydowanej większości od trzech, a niektórzy od dwóch lat do szkoły zakonnej.

W świetle wizytacji z 1823 roku monaster bazyliański w Żyrowicach, należał do najliczniejszych i najbogatszych monasterów prowincji litewskiej. Wszystkich bazylianów w Żyrowicach było 38, wśród nich zaś ponad połowa to zakonnicy w wieku ok. 20 lat. Klasztor miał solidne zaplecze, w którym kształtowała się formacja duchowa i intelektualna duchowieństwa unickiego. Edukacja prowadzona przez bazylianów żyrowickich przyciągała uczniów z różnych regionów. Kadra nauczycielska była wzbogacana przez bazylianów, którzy na kilka lat użyczali swojej posługi w szkole w Żyrowicach. Byli to m.in. Atanazy Falkowski (był wykładowcą teologii w Żyrowicach w latach 1782-83) ${ }^{61}$, Benedykt Lenartowicz (był wykładowcą teologii w Żyrowicach $)^{62}$. Wymienieni bazylianie swoje wyższe wykształcenie uzyskali w Rzymie. Po szkole żyrowickiej dalsze stopnie w nauce zdobywali bazylianie, studiując w Rzymie, m.in. biskup żyrowicki w latach 1828-1833 Ignacy (w zakonie: Jozafat) Bułhak h. Syrokomla ${ }^{63}$. Zazwyczaj bazylianów po ukończonych szkołach niższych, kształcono następnie w szkołach zakonnych, a zdolniejszych wysyłano na studia, najczęściej teologiczne i filozoficzne. W czytelni klasztornej biblioteki na ścianach umieszczone były płócienne tablice, które upamiętniały wszystkich metropolitów, arcybiskupów, biskupów, protoarchimandrytów bazyliańskich, nauczycieli żyrowickich i liczbę uczniów szkół żyrowickich, poczynając od 1725 r. ${ }^{64}$ Wychowanie w klasztorze żyrowickim w zdecydowany sposób wpłynęło na postawy bazylianów w czasach likwidacji unii.

Ze źródeł wynika, że większość zakonników pochodziła z terenów byłego Księstwa Litewskiego. Bazylianie wywodzili się z różnych środowisk społecznych, ale przeważały osoby pochodzenia szlacheckiego i mieszczańskiego. Rzadkością byli bazylianie o pochodzeniu chłopskim. W klasztorze pełnili różne funkcje, stanowiska i urzędy zgodnie

\footnotetext{
${ }^{61}$ Atanazy Falkowski (1736 - po 1818) z Łucka. Wstąpił do zakonu św. Bazylego (profesja 1763 w Byteniu). W latach 1772-73 przebywał w Kolegium Urbanum w Rzymie. Po powrocie z Rzymu był m.in. nauczycielem wymowy we Włodzimierzu Wołyńskim (1773-74) i wykładowcą teologii w Żyrowicach (1782-83). Ok. 1787 r. mieszkał w Wilnie, niedługo później został protoihumenem/prowincjałem (1788-92), wikariuszem generalnym (1793), protoarchimandrytą/przełożonym generalnym $(1794-95,1802)$ i wizytatorem klasztorów (1795-1802). Od 1803 r. na emeryturze w Torokaniach. S. Jujeczka, Klerycy z ziem polskich, litewskich i pruskich święceni w Rzymie (XVI-pocz. XX w.), Wrocław 2018, s. 235-255.

${ }^{62}$ Benedykt Lenartowicz (ok. 1774 - po 1847). W 1789 r. wstąpił do zakonu św. Bazylego. Uczył się w Torokaniach i Antopolu (1789-1790), studiował matematykę i fizykę na Uniwersytecie Wileńskim (1791-1795), teologię w Kolegium Urbanum w Rzymie (1795-1798). Po powrocie z Rzymu do 1807 r. uczył młodzież zakonną (m.in. w Podubisiu na Żmudzi, Borunach i Brześciu) różnych przedmiotów, m.in. języka francuskiego. Następnie uczył teologii w Żyrowicach, Wilnie, Borunach (1807-1814). W latach 1814-1818 był sekretarzem prowincji litewskiej, w latach 1818-1824 drugim konsultorem, w latach 1818-1822 superiorem w Wilnie, w latach 1822-1824 emerytem W Berezweczu. W 1824 r. został archimandrytą wileńskim, usunięty z urzędu po roku 1834 . W 1839 r. był archimandrytą czasowego klasztoru w Kursku, w 1842 r. po zamknięciu klasztoru zesłany został do Ławry Peczerskiej w Kijowie, gdzie zmarł. Wydał drukiem kazania, komentarze biblijne oraz bajki i opowieści. S. Jujeczka, Klerycy z ziem polskich, litewskich i pruskich święceni w Rzymie, s. 235-255.

${ }^{63}$ Ignacy (w zakonie: Jozafat) Bułhak h. Syrokomla (1758-1838). W 1774 r. wstąpił do Zakonu Św. Bazylego Wielkiego, uczył się następnie (a potem sam uczył) w zakonnych szkołach w Berezweczu i Żyrowicach. W latach 1782-1785 studiował w rzymskim Collegium de Propaganda Fide i uzyskał doktoraty z teologii i obojga praw. Po powrocie kaznodzieja w klasztorze w Wilnie. W 1787 r. koadiutor-biskup piński i turowski (konsekrowany 1790), w latach 1793-1795 biskup piński i turowski, w 1798 r. biskup brzeski, w 1818 r. arcybiskup kijowsko-halicki i biskup wileński, w latach 1828-1833 także biskup żyrowicki, w 1833 r. także arcybiskup połocki. S. Jujeczka, Klerycy z ziem polskich, litewskich i pruskich święceni w Rzymie, s. 235-255.

64 Архив СПб ИИ РАН, ф. 52, оп. 1, ед. хр. 374, л. 57.
} 
z doświadczeniem, wykształceniem i predyspozycjami (przełożonego, kaznodziei, spowiednika, parocha, ekonoma, trapeznego, szafarza, zakrystianina, dozorcy szkoły, archiwisty, nauczyciela). Z analizy źródła wynika, że większość zakonników uzyskała wykształcenie podstawowe i teologiczne w klasztorze. Wśród bazylianów przeważali zakonnicy, którzy kontynuowali naukę na poziomie uniwersyteckim. Studiowali nauki ścisłe i filozofię, a także teologię, zazwyczaj na Uniwersytecie Cesarskim w Wilnie. Obecność w klasztorze w Żyrowicach otworzyła większości bazylianów drogę do dalszej kariery, którą przerwała likwidacja unii w 1839 roku. Jak opisuje losy bazylianów w swoim pamiętniku ks. Samuela Czarnorucki (był uczniem studium zakonnego w Żyrowicach), to wykształcenie i ukształtowana tradycja religijna u większości zakonników potwierdzała silne przywiązanie do Kościoła unickiego i modelu życia zakonnego w formacji bazyliańskiej do końca życia.

\section{Bibliografia}

\section{Źródła rękopiśmienne}

Lietuvos Valstybes Istorijos Archyvas, Vilnius [LVIA], f. 634, op. 1, t. 58, k. 59-74; f. 567, op. 2, t. 2076 , k. 175 v-176; f. 567, op. 2, t. 682 , k. 87-88.

Lietuvos Mokslu Akademijos Biblioteka, Vilnius [LMAB], f. 3-892. - opis: „Jozafat Słobodzki O.S.B.M. post installationem in Superioram Monasterii Żyroviecenzis, Anno 1803”.

Narodowe Historyczne Archiwum Białorusi w Grodnie [НГАБ], Ф. 1, оп. 28, ед. хр. 708.

Sankt Petersburski Instytut Historii Rosyjskiej Akademii Nauk, Sankt Petersburg, Zespół nr 52 kolekcja Pawła Dobrochotowa, [Архив СПб ИИ РАН], ф. 52, оп. 1, ед. хр. 374 - opis: Wizytacja monasteru żyrowickiego z 1823 r., „Wiadomość o stanie klasztoru bazyliańskiego żyrowieckiego w gubernii grodzieńskiej, powiecie [...] diecezji brzeskiej położonego".

Архив СПб ИИ РАН, ф. 52, оп. 1, ед. хр. 202 - opis: „Klasztor Żyrowicki, Parafię i Szkoły Publiczne narodowe utrzymujący".

Архив СПб ИИ РАН, ф. 52, оп. 1, ед. хр. 153 - opis: „Visitatio monasterii Zyrovicensis a die 21 Aprilis 1720".

Архив СПб ИИ РАН, ф. 52, оп. 1, ед. хр. 305 - opis: „Alfabetyczny spis duchownych Kościoła unickiego: odnotowano nazwisko, imię, data urodzin, pełnione funkcje i urzędy oraz ewentualnie data zgonu. Cz. 4. Data wydania/powstania: [koniec XVIII w.]”.

Архив СПб ИИ РАН, ф. 52, оп. 1, ед. хр. 245 - opis: „Zdanie o braciach kończących filozofię w roku 1799 przez własnego ich profesora podane".

\section{Źródla drukowane}

Pjatidesjatiletie perenesenija Litowskoj duchownoj seminarii iz miesteczka Żirowice w gorod Wilnu 1845-1895, „Litowskija Jeparchialnyja Wiedomosti”, 1895, nr 40, s. 374-375.

Zapiski Iosifa, Mitropolita Litowskogo, izdannyje Imperatorskoju Akademieju Nauk, po zawieszczaniu awtora, t. 1, Sankt-Peterburg 1883.

Z notatek osiemdziesięcio-letniego starca Litwina Unity, „Przegląd Lwowski”, 1875, s. 100-108,148-153, 283-288, 488-493, 577-583, 629-634, 689-694, 765-772.

\section{Literatura}

Beauvois D., Wilno - polska stolica kulturalna zaboru rosyjskiego 1803-1832, Wrocław 2012.

Dobrowolski R., Szkoty bazyliańskie w Żyrowicach XVIII-XIX w., w: Małe miasta. Religie, red. M. Zemło, Lublin-Supraśl 2006, s. 411-467.

Dylągowa H., Dzieje unii brzeskiej, Warszawa 1996.

Dylągowa H., Kościót unicki na ziemiach Rzeczypospolitej 1596-1918, „Przegląd Wschodni”, 1992/1993, t. 2, z. 2 (6), s. 276-287. 
Fibek J., Tadulin - bazyliański klasztor p.w. Narodzenia NMP, http://www.radzima.org/be/object_ comm/7504.html (dostęp 23.04.2021).

Friedelówna T., Ewangeliarz Ławryszewski. Monografia zabytku, Wrocław-Warszawa-Kraków 1974. Giżycki J. M., Bazyliańskie klasztory unickie w obrębie prowincji białoruskiej, „Przewodnik Naukowy i Literacki”, 1907, t. 3, s. 186-187.

Giżycki J.M. (Wołyniak), Bazylianie we Włodzimierzu i Tryhórach, Kraków 1912.

Giżycki J.M. (Wołyniak), Siedziba bazylianów w Torokaniach, Kraków 1906.

Giżycki J. M., Wspomnienie o Borunach i unitach w Oszmiańskiem, „Muzeum”, 1907, t. 13, s. 645-666.

Jujeczka S., Klerycy z ziem polskich, litewskich i pruskich święceni w Rzymie (XVI-pocz. XX w.), Wrocław 2018.

Kołbuk W., Kościoły wschodnie na ziemiach dawnej Rzeczypospolitej 1772-1914, Lublin 1992.

Likowski E., Dzieje Kościoła unickiego na Litwie i Rusi w XVIII i XIX wieku, cz. 1-2, Warszawa 1906.

Lisiejczykaj D., Swjatar u bielarsukim socyumie: prasapagrafija unijackaga duchowieństwa 1596-1839 gg., Minsk 2015.

Mironowicz A., Biskupstwo turowsko-pińskie w XI-XVI wieku, Białystok 2011.

Mironowicz A., Likwidacja unii kościelnej na soborze połockim (1839 r.), w: Bizancjum - Prawosławie - Romantyzm. Tradycja wschodnia w kulturze XIX wieku, red. J. Ławski, K. Korotki, Białystok 2004, s. 147-155.

Mironowicz A., W związu z 150 rocznica synodu połockiego (1839-1989), w: Chrześcijaństwo w Związu Radzieckim w dobie pierestrojki i głasnosti, red. W. Grzeszczak, E. Śliwka, Pieniężno 1992, s. 138-146.

Niedziela Z., Szkoły bazyliańskie na Białorusi w świetle raportów Komisji Edukacji Narodowej, w: Unia brzeska. Geneza, dzieje i konsekwencje w kulturze narodów słowiańskich, red. R. Łużny, F. Ziejka, A. Kępiński, Kraków 1994, s. 183-199.

Nikałajeū N., Pałata Knihapisnaja, Minsk 1993.

Nowicka-Jeżowa A., Udział bazylianów w kształtowaniu kultury chrześcijańskiej na wschodnich Kresach Rzeczypospolitej, „Warszawskie Zeszyty Ukrainoznawcze”, 1997, nr 4-5, s. 240-251.

Radwan R., Carat wobec Kościoła greckokatolickiego w zaborze rosyjskim 1796-1839, Roma-Lublin 2001.

Rimskij S. W., Stosunki między Cerkwia prawosławna a państwem w Rosji w XIX wieku, w: Chrześcijaństwo w dialogu kultur na ziemiach Rzeczypospolitej, red. S. Wilk, Lublin 2003, s. 402-411.

Sorkina I., Mjasteczki Bielarusi u kancy XVIII - pierwszaj pałowie XIX st., Wilnja 2010.

Śliwa T., Kościól greckokatolicki na ,ziemiach zabranych” (1815-1839) i Kościół greckokatolicki w Królestwie Polskim (1815-1875), w: Historia Kościoła w Polsce, t. 2, cz. 1, red. B. Kumor, Z. Obertyński, Poznań 1979, s. 497-511.

Wereda D., Z dziejów sanktuarium i placówki oświatowej w Boruniach, „Nasza Przeszłość”, 2006, t. 105 , s. 189-206.

Wołczukowska J., Język „,słowiański” (ruski) w szkołach polskich za czasów Komisji Edukacji Narodowej, „Przegląd Rusycystyczny”, 1984, nr 4, s. 15-32.

Wołczukowska J., Zakonnicy jako nauczyciele języka rosyjskiego w szkołach Wileńskiego Okręgu Naukowego w latach 1787-1832, „Roczniki Humanistyczne”, 1988, t. 26, z. 7, s. 93-114. 